Review

\title{
Losses in the Grain Supply Chain: Causes and Solutions
}

\author{
Ákos Mesterházy ${ }^{1}$, Judit Oláh ${ }^{2,3, *}$ and József Popp ${ }^{3,4}$ 通 \\ 1 Cereal Research Non-Profit Ltd., 6701 Szeged, Hungary; akos.mesterhazy@gabonakutato.hu \\ 2 Faculty of Economics and Business, University of Debrecen, 4032 Debrecen, Hungary \\ 3 Faculty of Economic and Management Sciences, TRADE Research Entity, North-West University, \\ Vanderbijlpark 1900, South Africa; Popp.Jozsef@gtk.szie.hu \\ 4 Faculty of Economics and Social Sciences, Szent István University, 2100 Gödölő, Hungary \\ * Correspondence: olah.judit@econ.unideb.hu; Tel.: +36-2028-69085
}

Received: 27 February 2020; Accepted: 16 March 2020; Published: 17 March 2020

check for updates

\begin{abstract}
Global grain production needs a significant increase in output in the coming decades in order to cover the food and feed consumption needs of mankind. As sustainability is the key factor in production, the authors investigate global grain production, the losses along the value chain, and future solutions. Global wheat, maize, rice, and soybean production peaked at 2.102 million tons (mt) of harvested grain in 2018. Pre-harvest losses due to diseases, animal pests, weeds, and abiotic stresses and harvest destroy yearly amount to about $35 \%$ of the total possible biological product of $3.153 \mathrm{mt}$, with $1051.5 \mathrm{mt}$ being lost before harvest. The losses during harvest and storage through toxin contamination are responsible for $690 \mathrm{mt}$, with a total of $1.741 \mathrm{mt}$ or $83 \%$ of the total newly stored grain. Limited cooperation can be experienced between scientific research, plant breeding, plant protection, agronomy, and society, and in addition, their interdependence is badly understood. Plant breeding can help to reduce a significant part of field loss up to $300 \mathrm{mt}$ (diseases, toxins, water and heat stress) and up to $220 \mathrm{mt}$ during storage (toxin contamination). The direct and indirect impact of pest management on production lead to huge grain losses. The main task is to reduce grain losses during production and storage and consumption. Better harvest and storage conditions could prevent losses of $420 \mathrm{mt}$. The education of farmers by adopting the vocational school system is a key issue in the prevention of grain loss. In addition, extension services should be created to demonstrate farmers crop management in practice. A 50\% reduction of grain loss and waste along the value chain seems to be achievable for the feeding 3-4 billion more people in a sustainable way without raising genetic yields of crop cultivars.
\end{abstract}

Keywords: preharvest losses; postharvest losses; prevention of losses; plant breeding solution; sustainability

\section{Introduction}

Grain production is the basis of global food security and is indispensable for feeding the world. In 1798, Malthus argued that the global population increases more rapidly than global food supply until war, disease, or famine reduces the number of people [1]. The failure thus far of Malthus's prediction has not prevented others from promoting similar scenarios in more recent decades. For example, Paddock [2] forecasted a worldwide famine by 1975 and stated that within the short-term, it would be impossible to feed the population. Ehrlich and Ehrlich [3] predicted worldwide famine in the 1970s and 1980s due to overpopulation and urged action to control population growth. Just like Malthus [1] and Paddock [2], Ehrlich and Ehrlich [3] failed to appreciate the creativity of humanity. Romer [4] highlighted that a sustainable economy may be introduced in the future. Therefore, the green 
revolution introduced agricultural technologies that resulted in a doubling of grain production globally. More than 50 years have passed since the predictions of Paddock and Ehrlich, but mass starvation has not become widespread, although the number of undernourished and malnourished people has risen.

Nevertheless, many of Ehrlich and Ehrlich's [3] arguments related to resource scarcity appear to be close to reality because there are physical limits on natural resources. This has led Diamond [5] and other experts to shift the blame from "population" to "consumption." Fifty years ago, a growing population was highlighted as the main challenge facing humanity. Today, what really matters is people's consumption and production, which creates a resource problem. The principal challenge today is not population but total world consumption-namely, the product of local population times the local per capita consumption rate and it is not even consumption itself that is the major issue-only irresponsible and excessive waste, for which efficiency is the solution. The rational use of natural resources is the only way to avoid the global collapse of food, energy, and environmental security. Now we must take another step forward. We hypothesize that the problem is deeper and needs an even wider consideration to find more effective solutions or ways that will lead us towards a significant improvement.

1962 was the year of peak population growth, with a growth rate of $2.1 \%$. Subsequently, population growth slowed to $1.1 \%$ by 2015 . Global population will continue to grow until 2100; however, the rate of growth is expected to fall gradually to $0.1 \%$ annually [6]. The world's population reached 7.8 billion in 2020 and is projected to increase to 11.2 billion by 2100 (Figure 1). Can it realistically cover its grain needs?

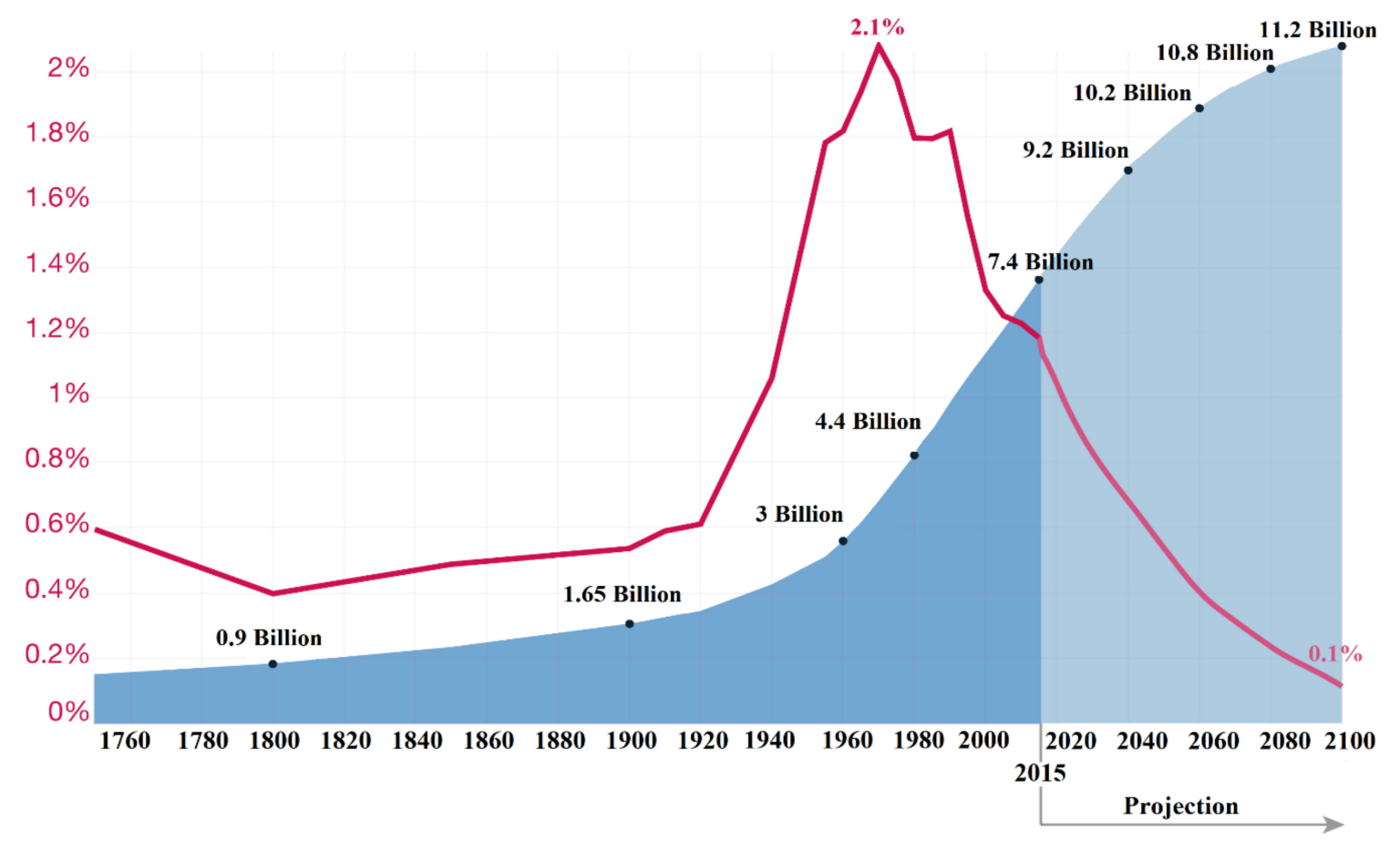

Figure 1. World population and growth rate, 1750-2015, and projections until 2100. Source: Roser and Ortiz-Ospina [7].

The goal of this study is to summarize losses along the grain value chain and identify more effective solutions. The problems at the pre-harvest and storage stages combined with mycotoxin contamination represent a very strong limitation, leading to huge losses of grains. This paper first presents the literature review on food loss (FL) and food waste (FW), followed by global grain production and losses along the grain chain including field, storage, mycotoxin contamination losses and consumer waste, a discussion of the role of integrated pest management, plant breeding, and agronomy in grain production and the implications for the future supply of grain for food and feed. Overall, this study 
explains the complexity of the grain value chain in order to make decisions on how best to prevent grain losses across the supply chain.

\section{Literature Review}

The world's population is predicted to reach 9.8 billion by 2050 and this will require an increase of $70 \%$ in food availability [6]. FL may occur due to technical limitations, such as a lack of proper storage facilities, infrastructure, packaging etc. [8]. FW is generated after the food is spoiled or expires due to poor stock management or neglect. FL takes place during the production, post-harvest, and processing stages, while food waste typically occurs at the retail and consumer levels. FL and FW can be evaluated and measured in different ways. There are several definitions of FL and FW taking into consideration pre-harvest and/or post-harvest stages, the use and destination of food, the edible part of food products, or the nutritional value of FL and FW [9]. The inclusion of pre-harvest stages to quantify food loss is essential because the pre-harvest management stage can increase the quantity and quality of tomatoes along the value chain [10]. FL and FW have negative food-security, economic, and environmental impacts. FL and FW represent the natural resources (water, land, energy) used to produce food. Reducing loss and waste throughout the food supply chain is an effective solution to mitigate the GHG emissions of agriculture and improve global food and nutrition security [8].

In 2011, the FAO estimated that annually around one-third of food produced is lost or wasted globally, which amounts to about 1.3 billion tons per year [11]. The 2030 Agenda for Sustainable Development (target 12.3) calls for halving per capita global FW at retail and consumer levels. FW represents a waste of resources (land, water, energy, soil, seeds, pesticides, etc.) used in its production; furthermore, it contributes to increasing GHG emissions. FL originates from decisions and actions by food suppliers in the value chain, excluding retailers, food service providers and consumers, while FW occurs from decisions by retailers, food service providers and consumers [12].

The global population will grow from its current 7.8 billion in 2020 to 9.8 billion in 2050 and global food demand is estimated to increase by at least $50 \%$, but demand for protein rich products may grow even faster [6]. Closing the food gap requires a decreasing rate of growth in demand by cutting FL and FW, reducing GHG emissions from agriculture, shifting the meat-based diets of high meat consumers towards a plant-based diet, innovation and a voluntary reduction of the birth rate in Africa [13]. According to BCG the annual FL and FW has reached 1.6 billion tons, worth ca. $\$ 1.2$ trillion USD, and by 2030 these figures may go up to 2.1 billion tons, worth about $\$ 1.5$ trillion USD [14]. Food lost or wasted annually accounts for one-third of global food production and $8 \%$ of global greenhouse gas emissions, while over 800 million people worldwide suffer from malnutrition. FL or FW along the food chain is most striking at the beginning and the end, namely in the production and transportation stage in developing regions, while it is more typical in the retail and consumption stage in developed countries. All stakeholders across the value chain can play a crucial role in food loss and waste reduction [15].

In North America (the US, Canada, and Mexico), annual FL and FW amount to 168 million tons. There are several opportunities to address FL and FW in North America including multi-stakeholder collaboration, standardized data labels, improved cold chain management, and processing and packaging innovation [16-18]. During processing, waste is generated by inadequate infrastructure and machinery, contamination, trimming and cutting problems, confusing date labels, food safety issues and cold chain problems [16-18]. About $40 \%$ of the annual US food supply is lost and wasted, so action is required across the food supply chain, with collaboration among agencies, businesses, and communities. The United States Government Accountability Office identified three key areas - limited data and lack of awareness about food loss and waste, and limited infrastructure - which should be addressed to cut FL and FW. In 2015, the US announced a goal to reduce national FL and FW by half by 2030 [19].

FL and FW accounted for approximately $20 \%$ of food produced in the EU with a value of $€ 143$ billion in 2015 [20]. Household expenditure on food indicates how food is valued in different 
countries. Household income spent on food in the EU is low as a proportion of income, on average $13 \%$. By contrast, in several African countries, almost $50 \%$ of income is spent on food. The share of FW in Europe was a few percent in the 1930s but has increased sharply since then to current global levels where one-third of food produced is lost or wasted. The relatively cheap food in the EU gives little economic incentive for consumers to avoid waste. In addition to FW, plastic waste is also a major economic, environmental, and social challenge. The overwhelming majority of plastic packaging is used only once. In the food supply chains, materials, including packaging, should be reduced, reused, and recycled in the framework of the circular economy [21].

According to a market study, up to $10 \%$ of food waste generated annually in the EU is linked to date marking; however, the market survey showed a high level of compliance. The authors conclude that FW linked to date marking can be reduced with a clear and legible date mark and consumers can make the distinction between "use by" (indicator of safety) and "best before" (indicator of quality). Nevertheless, significant FW prevention in relation to date labelling can be achieved in the dairy, fresh juices, chilled meat and fish supply chain [22]. Misinterpretation of food date labels is one of the key factors leading to FW. Date labels on food in the USA show a large variety of forms such as "use by," "best before," "sell by," and "enjoy by" dates, which are poorly understood by consumers. This paper makes recommendations on changes to the date labelling system in the USA and addresses actions needed to clarify the issue [23].

A survey conducted in Italy showed three key factors defining the extent of household FW, namely socio-demographic characteristics (household income spent on food), food shopping patterns and consumer behavior. More education and information are needed for the prevention of household FW [24]. Another study identified measures to combat FW along the food value chain in the metropolitan region of Barcelona and stressed the relevance of more research, since stakeholders oppose the introduction of new regulations and policies. Future research on the impact of new regulation including strong FW prevention measures is needed to reach a consensus and willingness among stakeholders of the food supply chain to implement new policies [25].

Conrad et al. [26] analyzed the link between FW, diet quality, nutrient waste and sustainability in the US. Higher quality diets lead to higher FW associated with greater amounts of wasted irrigation water and pesticides but less cropland waste due to the increasing consumption of fruits and vegetables included in higher quality diets, which have lower cropland and higher input needs compared to other crops. The results of the study show that simultaneously improving diet quality and reducing FW is a complex issue. Fanelli [27] found similarities in the structure of the food supply in relation to the quantity of animal-based products. The environmental impact of agriculture depends mainly on the structures of the food supply and agricultural practices applied in the different Member States of the EU. Consequently, large differences can be detected in the food supply of animal-based products and the GHG emissions intensity of the livestock sector. The farming system applied in the Member States should be based on the impact of agricultural practices on the environment to achieve a balance between livestock production and the intensity of GHG emissions. Furthermore, Fanelli [28] investigated the impact of agricultural activities on the environment in the Member States of the EU. She came to the conclusion that several Member States have similar production methods with a high impact on the environment; however, Mediterranean and northern Member States use traditional production methods including livestock grazing. Production methods with a high impact on the environment must be directed towards sustainable intensification.

The prevention of FW has become a global issue. In order to achieve this goal in developing countries a higher budget is needed for education, training and communication, technology implementation, and better infrastructure. Collaboration and dialogue between stakeholders along the food supply chain is crucial. Furthermore, data collection and comparable figures for different countries are needed, as well [29]. Ishangulyyev et al. [30] emphasized that FL and FW are complicated issues involving multi-stakeholders along the food supply chain; therefore, more research, collaboration, 
and awareness is needed for the prevention of FL and FW. Authors focus on awareness of the impacts of FL and FW leading to changing consumer attitudes and behaviors.

In China, Gao [19] reported an annual loss of $7.9 \mathrm{mt}$ for rice, wheat, and maize, but with advanced storage management, this can be reduced substantially. In India, the annual losses are estimated at $12-16 \mathrm{mt}$; however, losses are much higher at traditional farms, where $60-70 \%$ of the harvested grain is kept in short term storage facilities [31]. According to estimates by the FAO, in India the general FL and FW is around $40 \%$, but for cereals 30\% [32]. In the developing countries almost all pre-harvest and and post-harvest operations are conducted manually, therefore post-harvest loss accounts for $15 \%$ in the field, $13-20 \%$ during processing, and $15-25 \%$ during storage [33]. Smallholder farmers generally use conventional grain storage facilities, which are not effective against insects and mold. The replacement of these traditional storage structure with improved storage systems will maintain crop quality, reduce grain losses and food insecurity [34]. Up to $50-60 \%$ of cereal grains are lost during storage due to the traditional storage structures. Modern storage structures can reduce these losses up to $98 \%$, thereby increasing food security [35]. In Jordan, the total loss and waste along the wheat supply chain amounts to $34 \%$ associated with significant of losses of natural resources. Among postharvest losses, consumer waste ranks first, accounting for $13 \%$ [36].

\section{Materials and Methods}

Several methodological approaches can be used to identify household FW. Multivariate statistical techniques (descriptive statistics, principal component analysis, and hierarchical cluster analysis) were conducted to study the similarities and differences-namely the links between the structure of the food supply and the impact of agricultural practices on the environment between EU Member States [25]. Another study performed an exploratory online survey using a questionnaire adapted for studies on FW [24]. Furthermore, multivariate analyses was carried out for a comparative analysis of the environmental characteristics of the EU Member States with different agricultural systems [26].

The causes and prevention of losses along the grain supply chain is shown, based on the review of relevant literature and combining results from relevant studies and global models. Various combinations of the following terms were used to search in various papers: preharvest losses, postharvest losses, prevention of losses, plant breeding solution, sustainability. The literature on food security is already substantial; however, grain losses across the supply chain have not been addressed in detail. Furthermore, there is a lack of available publications relating to the causes of preharvest and postharvest grain losses. In addition, we also conducted supplementary searches by examining bibliographies of articles for additional references. The references of the paper mainly cover the period 2001 to 2019. References might differ in their focus on potential or realized FL and FW, their use of different baselines for comparisons, and other background conditions.

The FAO, OECD, International Grains Council, EU, and many other institutions publish serial data on grain production, use, trade, and prices. Other international sources issue estimates or data on grain losses before and after harvest. However, these data and information have not been aggregated and combined to make comparisons in order to calculate the benefits and trade-offs of grain production and losses at a global level. Data on food security related to production and losses have not been embedded into a global perspective. This paper attempts to combine all information collected to obtain a clear picture on the issue, which may serve the interests of multi-stakeholders along the grain supply chain. Other losses in the grain supply chain-losses in the conversion of feed into animal products, processing losses and over-consumption-have not been included in the calculation of grain losses and waste, and soybean losses and waste have also been excluded from our calculation.

\section{Global Grain Production}

Worldwide, wheat, maize, and rice are the most important cereal grains, and soybean is the major oilseed grain. The production volume and projected yield growth of grains are closely related to food security. The consumption of grains is projected to exceed supply, while supply is expected to grow 
at a higher rate than demand in the midterm (Table 1). Borlaug [37] also reported an increase in the deficit of grain production compared to consumption, primarily in developing countries. According to the forecast of the International International Grains Council [38], yield increase is expected to grow from $0.8 \%$ to $1.5 \%$ annually from $2013 / 2018$ to $2020 / 2024$.

On the other hand, the increase in consumption is projected to decrease from $2.1 \%$ to $1.0 \%$ on average in the same period. So, the gap between the supply and demand of grains is shrinking leading to a decreasing accumulated deficit of about 155 million tons $(\mathrm{mt})$ between production and consumption over the period of 2017/2018-2023/2024. The consequence of the downward trend in supply is a fall in the carry-over stock level from $29 \%$ to $21 \%$ between 2017/2018 and 2023/2024, making supply in critical years more problematic. However, data on supply and demand between years may vary strongly. Grain prices are expected to be higher than in past years in both real and nominal terms due to shrinking stock levels. This means that a robust increase in production cannot be expected; therefore, we should investigate how to feed the global population and livestock. The yearly change for the next years $(\mathrm{y} / \mathrm{y})$ is projected at $1.5 \%$ for production, $1.0 \%$ for consumption and $1.5 \%$ for exports accompanied by a slow decrease of carryover stocks. For this reason, much greater attention must be given to losses along the food chain.

Table 1. Forecast for global grain production (wheat, corn, rice and soybean), 2017/2018-2023/2024 (million tons).

\begin{tabular}{|c|c|c|c|c|c|c|c|c|c|}
\hline Total Grains & $17 / 18$ & $18 / 19$ & $19 / 20$ & $20 / 21$ & $21 / 22$ & $22 / 23$ & $23 / 24$ & $\begin{array}{c}5 y \\
\text { Average } \\
2013 / 2018\end{array}$ & $\begin{array}{c}y / y \\
\text { Change, \% } \\
2020 / 2024\end{array}$ \\
\hline Production (M t) & 2.102 & 2.089 & 2.120 & 2.149 & 2.181 & 2.213 & 2.246 & $0.8 \%$ & $1.5 \%$ \\
\hline Consumption (M t) & 2.107 & 2.137 & 2.156 & 2.179 & 2.201 & 2.226 & 2.249 & $2.1 \%$ & $1.0 \%$ \\
\hline Exports (Jul/Jun, M t) & 367 & 368 & 371 & 377 & 383 & 390 & 396 & $5.5 \%$ & $1.5 \%$ \\
\hline Carryover Stocks (M t) & 614 & 566 & 530 & 500 & 480 & 468 & 465 & $3.2 \%$ & -3.8 \\
\hline y/y change & -5 & -48 & -36 & -30 & -20 & -12 & -3 & - & - \\
\hline Stocks to use ratio, $\%$ & $29 \%$ & $26 \%$ & $25 \%$ & $23 \%$ & $22 \%$ & $21 \%$ & $21 \%$ & & \\
\hline
\end{tabular}

Source: International Grains Council [38].

On the production side, further substantial increases in yield will be constrained. Obviously, technology, plant breeding, improving agronomy, and new production methods will resolve this phenomenon to a certain extent. Higher yielding cultivars are on the market, but their effect on yield is only moderate as the genetic capacity of these cultivars is just partly exploited. Without making long-term predictions of the global grain supply the problem described above must be approached from a different perspective. We have to focus on causes and solutions of food and feed losses along the grain supply chain.

\section{Losses along the Grain Chain}

The reduction of grain losses by biotic factors (pests, pathogens and weeds) is a major challenge for food supply [39]. In addition to pre-harvest losses, the losses occurring during transport, pre-processing, storage, processing, packaging, marketing and plate waste are also substantial (Figure 2). Reduction of losses results in a higher revenue than an increase in genetic yield ability [40]. Globally, an average of $35 \%$ of potential crop yield is lost to pre-harvest pests [41]. In addition to pre-harvest losses, the losses occurring during transport, pre-processing, storage, processing, packaging, marketing, and plate waste are also substantial [39]. By reducing FL and FW, food security combined with resource efficiency can be enhanced. In 2011 the European Commission set targets to halve the disposal of edible FW by 2020, and in 2012, the European Parliament also issued a resolution to halve FW by 2025 and designated 2014 as the "European Year against Food Waste" [42,43]. The problem is that the EC targeted only edible FW excluding other forms of waste, for example in feeding. 


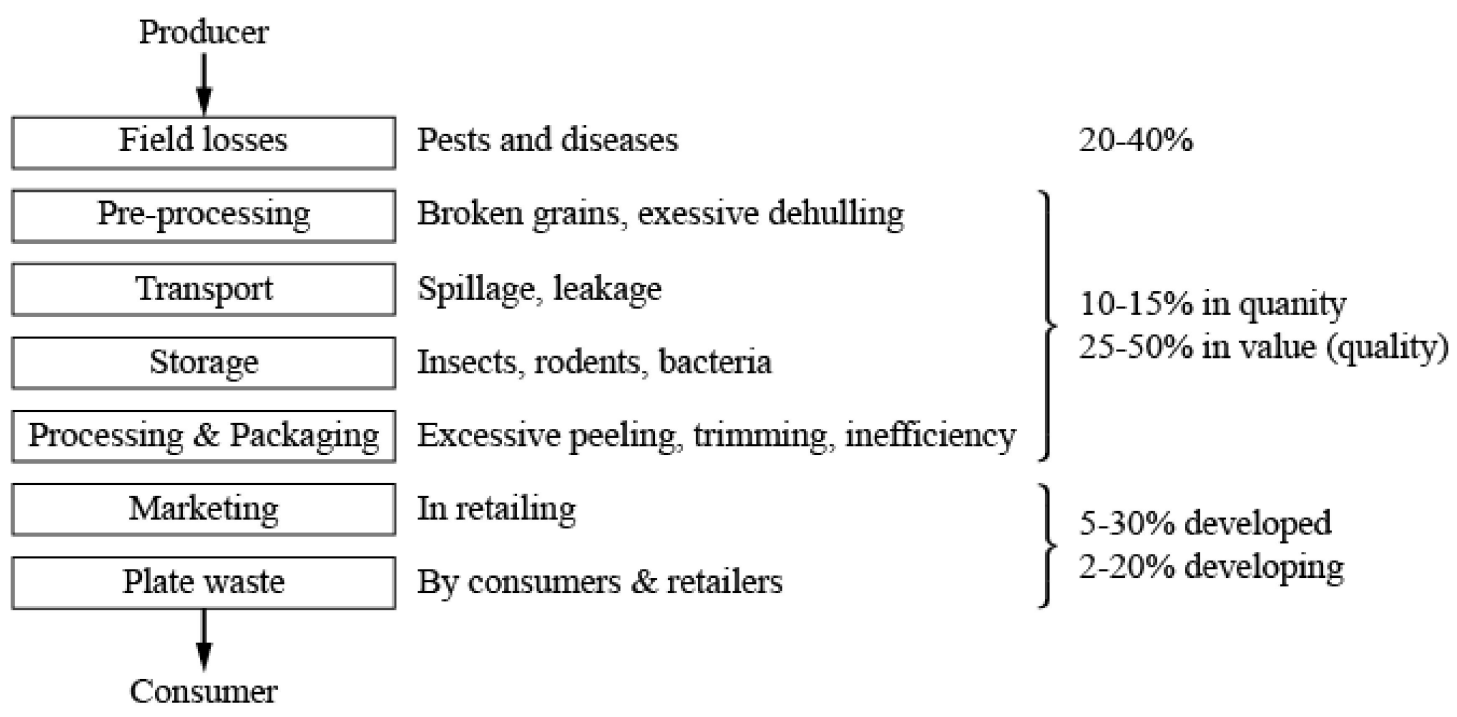

Figure 2. Losses along the food chain. Source: International Water Management Institute [44].

Each stage of the grain value chain is a source of grain losses and waste, each with a different loss ratio. The problem needs a multidisciplinary approach [45,46], but in spite of efforts we are far from the solution. Therefore, our goal was to summarize losses along the grain value chain and identify more effective solutions. The increasing loss and waste of grains reduce food security and also negatively affect sustainable development (natural resources, environment and human health) [47,48]. In addition to the actual loss and waste, resource inputs, e.g. arable land, irrigated water, fertilizer and energy, are also lost and wasted Gustavsson et al. [11] contributing to higher cost for a unit of really consumed product.

In 2018, global grain production accounted for 2.102 million tons [38]. The data we used for losses are based on estimates in the literature. However, the different sources produce comparable numbers. We used the lower estimates for increased reliability. It is well known that the loss expressed in monetary term is very high at lower quality or high toxin contamination even the amount of losses does not change much. For example, toxin contamination can cause 100\% income loss at minimal yield reduction. Approximately one-third of potential crop yield is lost to pre-harvest pests, pathogens and weeds. The theoretical yield would account for $3.153 \mathrm{mt}$ per annum and pre-harvest losses amounts to 1.051 million $\mathrm{mt}$. Grain losses at harvest are estimated at $3 \%$ or $60 \mathrm{mt}$ annually, with wide regional variations between small and large farms. Total pre-harvest and harvesting losses account for about $1.110 \mathrm{mt}$ per year. In addition, $420 \mathrm{mt}$ of grains are lost during storage, 210 million tons due to field mycotoxin contamination (excluding consumer's waste of $286 \mathrm{mt}$ annually (Table 2). It can be concluded that one third of the possible yield is lost before harvest, another $20 \%$ is wasted due to storage and mycotoxin contamination, and only one third of the grain total production potential is really consumed, including consumer waste of around $10 \%$ ). 
Table 2. Losses of grains along the full value chain in 2018 (million tons).

\begin{tabular}{cccc}
\hline Items & Million Metric Tons & \% to Total Capacity & \% to Harvest \\
\hline Total production capacity & 3.153 & 100.00 & \\
Total harvested yield & 2.102 & 66.67 & 100.00 \\
Losses due to biotic and abiotic factors & 1.051 & 33.33 & 50.00 \\
Harvest losses (cc 3\%) & 60 & 1.90 & 2.85 \\
Storage losses & 421 & 13.35 & 20.03 \\
Field mycotoxin contamination & 210 & 6.67 & 9.99 \\
Consumer's waste & 286 & 9.07 & 13.61 \\
Total loss & 2.028 & 64.32 & 96.50 \\
Total grain consumed & 1125 & 35.68 & 0.00 \\
\hline
\end{tabular}

Source: Authors' own calculation based on the production data of International Grains Council [38].

\subsection{Field (Pre-Harvest) Losses}

Yield losses caused by pests, pathogens, and weeds are major challenges to crop production. Increased use of plant protection increased crop harvests from $42 \%$ of the theoretical worldwide yield in 1965 to $70 \%$ of the theoretical yield by 1990; however, at least $30 \%$ of the theoretical yield was still being lost due to ineffective pest-management methods applied in several regions of the world. Without plant protection, $70 \%$ of crop yields could have been lost to pests [41]. Actual losses were estimated at $26-30 \%$ for soybean and wheat, and $35 \%$, and $40 \%$ for maize and rice, respectively [ 40 ]. Cramer [49] estimated crop losses of around $28 \%$ due to all pests in North and Central America. Russel (1978) cited over 50\% yield losses caused by pests, pathogens and weeds worldwide. Schumann and D'Arcy [50] estimated the loss of yield caused by all pests at some $20 \%$ despite the billions of dollars spent on plant protection. According to Ubrizsy [51], in the 1960s mean yield loss for all crops caused by pests, pathogens and weeds stood at $15-20 \%$ and $25-30 \%$, respectively. Actual losses were estimated at $36 \%$ for wheat and 38\% for maize on average during the period 1950-1960 excluding yield loss caused by abiotic factors (temperature, humidity, rain, floods, etc.).

It is well known that plants would not survive a crisis-level water shortage because under a certain level of precipitation plants cannot cope with water stress. In Hungary, yield sensitivity to droughts show that maize and wheat yield reduction may reach up to $50 \%$ in drought seasons. The effects of drought play a large role in damage to crops, depending on soil quality. Drought conditions can have a moderate impact on good soil or a profound impact on sand. The yield loss in drought and dry seasons reaches one-third on average. Beyond the $35 \%$ loss due to biotic factors, we did not count extra losses for abiotic losses, as in drought years, diseases, insects, and weeds normally cause significantly less damage. The authors aimed to make a conservative estimate that is close to reality. Aflatoxin is an exception in draught and hot years, but in yield reduction it is not important.

\subsection{Integrated Crop Management}

Integrated crop management (ICM) is an environmentally sensitive and economically viable production system by using the latest available techniques to produce high quality food in an efficient manner [52]. Reductions in pest control costs and in the use of pesticide in ICM programs can be achieved by introducing populations of natural enemies, variety selection, applying alternative pesticides, etc. For farmers, the main benefit of ICM is still a reduction in pesticide use, although most programs still rely heavily on pesticides [39]. The main task of ICM is not to decrease pesticide costs but it contributes to the production of healthy food. The present production level is a consequence of contemporary pesticide use, but the losses that could not be prevented show that a significant development is necessary.

Bajwa and Kogan [53] listed 67 definitions for integrated pest management but did not mention resistance to pests. Ehler [54] focused on integrated pest management but also mentioned integrated 
pesticide management because it is not the pests themselves, but rather the use of pesticides, that should be better managed in order to reduce the occurrence of pests.

Kumar and Shivay [55] took a step forward by combining pest management with seedling establishment and nutrient management. Vanlauwe et al. [56] highlighted integrated soil fertility management, focusing on the efficiency of fertilizer use. Bottrell [57] reported on integrated pest management, while Barzman et al. [58] summarized the most important principles with the objective of optimizing the use of pesticides but did not mention resistance as a possible influencing agent, only considering pesticide reduction.

Lehoczki-Krsjak et al. [59], Mesterhazy and Bartok [60], Mesterházy [61], Mesterházy [62], Mesterházy et al. [63], Mesterházy et al. [64], and Mesterházy et al. [65] were among the first to indicate the decisive role of the resistance level increasing the effect of fungicides against Fusarium head blight in wheat. Actually, the resistance level regulates the fungicide effect. Lamichhane et al. [66] stressed the role of resistance in sustainable and low-input agricultural systems and the role of breeding cultivars with the resistance traits required for organic production. Nevertheless, in a wider context we need to integrate plant breeding, water management, and storage conditions with an emphasis on the fungi that normally cause less grain loss. It is possible to keep the whole production process under control by the introduction of Intelligent Field Crop Management (ICM).

\subsection{Storage Losses}

Storage plays a central role in the grain supply chain. Grain storage losses are affected by several factors, including direct and indirect losses. Direct losses are related to the physical loss of grains, and indirect losses occur due to loss in quality and nutrition [35]. Storage losses can be classified into biotic factors (insect, pests, rodents, fungi) and abiotic factors (temperature, humidity, rain). Moisture content and temperature affects storage life. For example, storage molds spread rapidly at higher temperatures and humidity. Damage and losses caused by insects and rodents can refer to physical deterioration (e.g., holes in the grain) and quality (value) loss. Huge direct and indirect storage losses are reported in developing countries. Jayas [67] estimated losses as low as 1-2\% in developed countries using metal silos compared to $20-50 \%$ in developing countries where grains are generally stored by family farms in traditional storage structures. According to Manandhar et al. [34] in most developing countries up to $80 \%$ of cereals are produced by small family farms where grain losses can go up to $15 \%$ in the field, $13-20 \%$ during processing, and $15-25 \%$ during storage, giving total losses of $43-60 \%$. Grain losses in storage account for 10 to $20 \%$ of stored products, as a result of damage caused by insects [68]. By calculating an average storage loss and damage of up to $20 \%$ of stored grain worldwide, approximately $420 \mathrm{mt}$ of grains are lost during storage annually.

The storage and handling methods should minimize losses. Before storage the grain must be cleaned and contaminants (dust, insects, straw, chaff, weed seeds, etc.) removed. Furthermore, test for toxins is mandatory before storage and grains of low, medium and high contamination level must be stored separately from each other. Critical physiological factors (moisture content and temperature) affect the storability of crops because high moisture content and heat cause fungal and insect problems, therefore humidity temperature and $\mathrm{CO}_{2}$ control is highly important. Introducing best practices for handling and storage is a cheaper solution compared to the loss of grains during storage.

\subsection{Mycotoxin Contamination}

Mycotoxins are toxic chemicals unsuitable for animal feed and human consumption. High concentrations of aflatoxin can pose a serious health risk both to humans and livestock. A significant concentration of toxin levels is frequently measured even during harvest, leading to the need for control measures, both pre- and post-harvest. The most important source of the mycotoxin problem is the generally high susceptibility of the grain crops. Large toxin epidemics in the fields are always consequences of an epidemic. WHO estimated that $25 \%$ of the world's crops are contaminated by mycotoxins excluding considerable preharvest losses [69]. Up to $25-40 \%$ of global 
cereal grains are contaminated by the mycotoxins produced by fungi Kumar et al. [70]. Dowling [71] reported, based on UNO and FAO data, that $25 \%$ of the world grain crop is significantly contaminated by mycotoxins.

McMullen et al. [72] reported that due to nearly yearly epidemics in the USA the acreage of wheat was reduced from 29 million ha (1992) to 21.4 million ha (2010). The same numbers for barley are 2.9 and 1.0 million ha. This is normally not taken into consideration. The high toxin contamination of harvested yield caused additional quality loss and a reduction in prices of $50-90 \%$. The yield and quality losses amounted to billions of dollars. Similar losses were also recorded in epidemic years in Canada, Europe, and China. Maize is a more complicated problem. Szabo et al. [73] estimated losses in maize in 2014 at about 300 million dollars, with nearly no yield reduction. The contaminated grain (deoxynivalenol, zearalenone, fumonisins) decreased the price of harvested grain by about $\$ 32 \mathrm{USD} / \mathrm{t}$ or $25 \%$, while the rest of the loss was attributed to animal husbandry by lower weight gain, sexual disorders, higher death rates, cost of toxin bindings and antibiotics, etc.

This means that yield loss on its own does not show the significance of the problem. The damage caused by toxins during storage represents about $10 \%$ yearly loss at a conservative estimation and removes $210 \mathrm{mt}$ of grain per annum globally. This amount represents stored grains and does not include the infected and light grain part in small grains blown out by the combine at harvest, which cannot be measured, but exists. Due to toxin regulations the human population is well protected in the developed world, but this is not the case in many countries where animal husbandry the situation is similar-contaminated grains are normally used in animal husbandry In small grains cleaning systems, optical selection of infected grains can reduce toxin levels, but the cost is relatively high equivalent to a yield loss of $10-20 \%$. In maize, however, such effective methods are in experimental phase. Most of the toxins are of field origin detectable at harvest, but bad storage conditions can cause significant increases. In order to minimize grain losses, fungi formation must be addressed during storage.

\subsection{Consumer Waste}

Plate waste of food is as high as $5-20 \%$. In developing countries, FL and FW including plate waste is higher than in developed countries. FL and FW depend on technology and on consumer behavior. 1.3 billion tons of food or $1 / 3$ of all food produced for human consumption is lost or wasted from harvest to consumption annually, without accounting for losses in livestock production worldwide [11,74]. Carrying out evidence-based FL and FW calculations still presents an open challenge. In estimating FW, the most critical research gap is related to the lack of a clear definition of FW and a harmonized FW accounting methodology [75]. In developed countries, consumers throw away $286 \mathrm{mt}$ of cereal products [76]. Just taking into consideration maize, wheat, and rice, at least $200 \mathrm{mt}$ of cereals are wasted by consumers per annum globally (soybean loss and waste is not included).

\subsection{Breeding Versus Food Losses}

Research has clarified that resistance is the most important toxin regulator $[61,62,65,77,78]$. However, large resistance differences occur, in wheat Fusarium head blight deoxynivalenol concentration varied between $5 \mathrm{mg} / \mathrm{kg}$ and $400 \mathrm{mg} / \mathrm{kg}$ at the higher epidemic pressure in 2001-2002 [78]. According to literature sources there is no effective means for solving toxin contamination before harvest Jans et al. [79] stressing the preharvest prevention of disease and toxin by resistance. This is a problem as this also inhibits breeding activity and creates difficulties for stakeholders. The results of the wide international literature do not support this view. Ten- to 20-fold resistance differences also exist in toxin response; therefore, this problem should be exploited.

Resistance also influences further fungicide efficiency and improves the predisposition of plants to previous crops with high pathogen population [80]. Disease and toxin forecasts will be better when resistance levels are considered [81]. Zorn et al. [82] indicated that ploughing was as effective a way to reduce deoxynivalenol (DON) as planting a more resistant variety, and in other diseases the experiences are similar. Breeding for adaptation to different soil and climatic conditions is essential. 
Tolerance to acidic soils is also a breeding problem among many others. Minimum tillage and organic production needs plants that are highly resistant against the most important diseases, as in these cases the disease pressure can be significantly higher as effective fungicide are forbidden to use. Resistance to biotic and abiotic factors brings a direct and significant improvement to yield, quality stability and adaptation. Breeding for more efficient fertilizer use in order to improve the photosynthetic activity, adaptation etc. of the plants has also its place. The main problem is that the extensive knowledge available in the scientific community suffers from a bottleneck effect when it should be applied in plant breeding. Most breeding firms are small, with 1-2 breeders for a plant or less, and they lack any laboratory background or support from trained scientists. This is true also for European family companies. The large firms concentrate on high yields but often neglect food safety and other problems, so varieties with high yields often produce severe financial losses.

Unsatisfactory breeding efforts contribute to $210 \mathrm{mt}$ loss due to toxin contaminated grains. Much of the storage microbes are of field origin, so lack of resistance might be partly responsible for storage losses. The devastating effect of storage microbes is characteristic when storage conditions are bad, however, most of the losses could be prevented by advanced storage technology. Storage microbes cause about $50 \%$ of storage loss, i.e. 210 million $\mathrm{mt}$ of grain per annum; therefore, mycotoxins of field and storage origin are treated separately because they need to be treated using different approaches.

\subsection{Agronomy}

The keys to the green revolution, whose father was the Nobel laurate Norman Borlaug, were improved seeds, especially the short straw lodging resistant wheat varieties giving higher yields due to a better harvest index and resistance to diseases such as rust. The breeding program was led by Norman Borlaug and supported by inputs (chemicals and fertilizer) and irrigation water [83]. The green revolution spread in all developing and developed regions and helped more than one billion people to survive. The key factor was to find a connection between breeding and agronomy that helped to exploit the greater abilities of the new varieties. This is essentially an update the basic ideas of the Green revolution by Baranski [83] adapted to present needs and balancing the negative effects of climate change.

Breeding for more yield resulted in increasing nitrogen and water dependence. We can mention possible shortage in phosphorus and potassium. Today, several breeding companies are focusing on shorter season crops, less water use, and gene editing, among other things. There is an improving efficiency of utilization of nitrogen, potassium, phosphorus, but insufficient supply of microelements is also a growing problem. The decoupling of nitrogen from yield dependence is another central research area. Nevertheless, breeding for higher yields still has priority. Wang et al. [84] summarized the possibilities for wheat, but similar patterns exist also for other crops. Pest management is also relevant in agronomy to protect grain against pests, pathogens, and weeds. Effective disease control is indispensable in epidemic years. However, the contemporary storage needs also pesticides for insect control and specific fungicides against diseases.

\section{Discussion}

In order to explain the possible shortage of food globally, Malthus [1] warned about overpopulation. He did not take into consideration the fact that more food required could be produced due to scientific and technological development. The forecasted mass starvation has so far not become a reality. Diamond [5] blamed consumption, especially overconsumption in the developed world. The present global food production is not sustainable and accompanied by huge losses and wastes along the value chain. For this reason, agricultural production needs a reorganization with specific local solutions for particular regions.

Half of total losses occur before the process of harvesting begins representing $1051.5 \mathrm{mt}$ annually. This makes production per unit more expensive. Among the causes of crop losses, the bottleneck effect between basic, applied research, and breeding must be highlighted, which means that most of the 
available existing knowledge does not reach, for example, those involved in breeding, plant protection, agronomy, etc. Consequently, the effectiveness of the combination and utilization of the knowledge adapted for local and regional breeding, agronomy, etc. is very poor and the results are embarrassing. More knowledge is needed about the interrelations between disease resistance, yield ability, and the efficacy of pesticides and agronomy responses at cultivar level to develop the optimum mix of different procedures for each region and field. At least two third of grain field losses, namely $700 \mathrm{mt}$, are related to biotic stresses. Plant breeding is supposed to be responsible for about a third of this amount $(233 \mathrm{mt})$. However, it is impossible to breed for resistance against 200 diseases of a crop. Plants are generally treated for the 4-5 most important diseases by farms; therefore, resistance and pesticide treatments should be combined. For the rest of the losses (roughly $500 \mathrm{mt}$ ) correct pest management and agronomy measures combined are needed. Suggestions made by Lamichhane et al. [66] for organic culture are also necessary for conventional plant production. Near Szeged (southern Hungary), Mesterházy et al. [64] and Mesterházy et al. [65] reorganized the crop structure and fungicide program and tillage for wheat. Without any additional cost, the wheat yield became much healthier (fewer toxins and leaf diseases), and a $4-5 \%$ yield increase could be achieved on about 2000 ha of wheat.

Grain production is expected to expand well below the growth rates of the last decades. Yield increase will not be sufficient to achieve global food security. The potential increase in maize, wheat, rice and soybean yields will be less than $10 \%$ in the next five years, resulting at the most in 220 million mt of extra yields. Comparing the projected extra yields of grains for the next five years, with the annual losses and waste of about $980 \mathrm{mt}$ excluding pre-harvest losses, it becomes apparent that reducing food loss and waste can help to enhance food security more efficiently then yield increase can. The slowdown in global annual yield growth is the main challenge facing global food security. Maize, rice, wheat, and soybean together produce about $64 \%$ of global agricultural calories (of this maize, rice, and wheat $57 \%$ ) and decreasing yield gains in these crops will have serious implications for the global grain supply chain [85]. Grain yields are affected by both biophysical and socioeconomic factors worldwide leading to increased yield variability in the future. Climate-change-related heat stress, scarcity of water for irrigation, depletion of soil fertility and salinization, soil erosion, pest and disease build-up and a lack of capital will have a greater impact on yield development than the genetic improvement of grain cultivars. In Europe, yields are affected by climate change in several EU member states.

Moreover, agricultural subsidies are tied to the reduction of environmental burden and agricultural inputs, leading to yield stagnation. For this reason, the reduction of loss and waste is the most important factor in achieving food security with a much larger impact on the grain supply for food and feed than higher yielding crops. Breeding for yield stability and resistance combined with advanced pest management strategies, improved agronomy and storage could reduce grain losses and waste by at least 50\% and meet the demand for grain for an additional 3-4 billion people globally.

At least two third of the field losses namely $700 \mathrm{mt}$ are related to biotic stresses. Plant breeding is supposed to be responsible for about a third of this amount $(233 \mathrm{mt})$. However, it is impossible to breed for resistance against 200 diseases of a crop. Plants are generally treated for the 4-5 most important diseases by farms; therefore, resistance and pesticide treatments should be combined. For the rest of the losses (roughly $500 \mathrm{mt}$ ), both correct pest management and agronomy measures are needed.

\section{Conclusions}

Increasing global population and decreasing natural resources associated with growing FL and FW have resulted in an unprecedented challenge. Transforming a wasteful food supply chain into a sustainable food solution needs collaboration between researchers and multi-stakeholders in the food supply system. This conclusion is in line with several studies $[16,19,29,30]$. We have to understand the key drivers causing FL and FW across the food supply chain and find solutions for reducing these losses and waste. The field of FL and FW lacks appropriate metrics used to calculate benefits and trade-offs. Stakeholders in the food supply chain have incomplete data about how much FL and FW is 
generated or the total costs of its management to make these comparisons. This outcome is supported by other reviews as well $[9,10]$.

The results show that cumulating harvesting, storage and toxins losses along the grain supply chain may reach up to $690 \mathrm{mt}$ annually, excluding the $1.051 \mathrm{mt}$ of pre-harvest losses. Besides pre-harvest losses, the highest rates of loss are associated with storage and mycotoxin contamination. Breeding, cultivation, plant protection, harvesting, storage, handling, and transportation practices play key roles in the efficiency of the grain supply chain. Grain loss in the future depends on technology and the workforce. In addition, consumer waste is based on consumer behavior and food waste management.

At present, a significant increase in global grain production only by the introduction of new higher yielding varieties is not possible. What are the limitations? Interestingly, it is not the shortage of inputs, such as fertilizers, chemicals, etc., that plays an important role in restricting increases in the yield and quality of cereals. The shortage of water is an acute problem on one side, with research on the other. Cooperation among those involved in breeding to increase yield, to improve resistance to biotic and abiotic stresses and agronomy is poor, as these fields largely work separately from each other and their positive innovative effects are not utilized to the extent that could be possible. Special problems occur in the field of toxigenic fungi. However, in recent decades screening and genetic methods have been used to increase resistance levels. The problems at the harvest and storage stages represent a very strong limitation, leading to losses of several hundred million tons of grains. In many regions of the globe poor infrastructure is also a strong limiting factor, inhibiting the application of modern logistics, installations, machines etc. The lack of special education is a very strong limiting factor causing very high losses before and after harvest. This conclusion is consistent with previous studies [24,29,30].

How do we prevent a significantly higher amount of loss? Plant breeding must consider closely global needs and local activity in order to reach the highest adaptation of the cultivars bred, because cultivars have to resist to different challenges of both biotic and abiotic stresses. We face a special problem in stresses such as drought, heat, toxic fungi, and leaf spots that inherit mostly polygenic traits and so breeding is more complicated than in the case of monogenic traits. We should be aware that each crop has about 200 pathogens, of which 4-5 can be treated in a breeding program, indicating the need for chemical control when a new disease appears in the field. A much higher resistance is needed against toxigenic fungi; therefore, crop production must be much better adapted to local conditions. The finding is in line with previous literature [28].

About 20 years ago, we spoke about integrated crop management to reduce pesticide use. Today, Intelligent Field Crop Management is spreading. It is necessary to evaluate for each field the optimal mix of variety, agronomy, pesticide application, irrigation, and previous crop selection to ensure maximum possible yield by using necessary pesticides. Harvest and storage management should be modernized. The current best available technologies reduce loss during storage by $2-3 \%$ without quality reduction. This outcome is in accordance with the studies published by $[8,19,34,35]$.

In order to prevent grain loss farmers should be educated globally; the extension service in the US can be an example to follow. Demonstration farms can show farmers how intelligent field crop management works in practice. The vocational school system should also be adopted to meet these new challenges. The production method used in developed countries should also be applied in the developing world. Developed countries also face new problems, including the ecological crisis, therefore new solutions are needed through global action and scientific innovation. Local agricultural development programs can solve local problems, but international organizations must support and harmonize the global and local network.

Agriculture is a capital and knowledge-intensive sector, so huge agricultural investments must be made in the next few decades to meet the challenges of the growing yield demand for grain, and at the same time to maintain a sustainable environment. Therefore, reducing global losses and waste along the grain supply chain is the most effective way to increase global food and nutrition security. This needs long term thinking and not short run profit at a maximum level. For this reason, national 
and global regulations, investment and scientific policies are preconditions to provide reasonable and sustainable solutions for the future; however, the largest task is to change the way we think.

Author Contributions: Á.M. and J.P. conceived and designed the experiments. Á.M. and J.P. contributed analysis tools. Á.M., J.O. and J.P. wrote the paper. All authors have read and agreed to the published version of the manuscript.

Funding: This research received no external funding.

Acknowledgments: The authors are indebted to the projects MycoRed FP7 (KBBE-2007-2-5-05 (2009-2012), GOP 1.1.1.-11-2012-0159 EU-HU (2012-2013), GINOP-2.2.1-15-2016-00021 (2016-2020) and TUDFO/5157/2019/ITM for financial support. This research was supported by the ÚNKP-19-4-DE-147 New National Excellence Program of the Ministry for Innovation and Technology and by the János Bolyai Research Scholarship of the Hungarian Academy of Sciences.

Conflicts of Interest: Authors declare that there is no conflict of interest.

\section{References}

1. Malthus, T.R. An Essay on the Principle of Population as it Affects the Future Improvement of Society, with Remarks on the Speculations of Mr. Goodwin, M. Condorcet and Other Writers, 1st ed.; J. Johnson in St Paul's Church-yard: London, UK, 1798.

2. Paddock, W. Famine-975! America's Decision: Who Will Survive? Little, Brown and Company: Boston, MA, USA, 1967.

3. Ehrlich, P.R.; Ehrlich, A.H. The Population Bomb Revisited. Electron. J. Sustain. Dev. 2009, 1, 63-71.

4. Romer, P.M. Two strategies for economic development: Using ideas and producing ideas. World Bank Econ. Rev. 1992, 6, 63-91. [CrossRef]

5. Diamond, J. Collapse: How Societies Choose to Fail or Succeed; Viking Penguin/Allen Lane: New York, NY, USA; London, UK, 2005.

6. United Nations. World Population Prospects: The 2017 Revision; United Nations, Department of Economic and Social Affairs, Population Division: New York, NY, USA, 2017. Available online: https://www.un.org/ development/desa/publications/world-population-prospects-the-2017-revision.html (accessed on 15 January 2020).

7. Roser, M.; Ortiz-Ospina, E. World Population Growth, Our World in Data. 2017. Available online: https://ourworldindata.org/world-population-growth (accessed on 15 January 2020).

8. Food and Agriculture Organization of the United Nations. Global Initiative on Food Loss and Waste Reduction; Food and Agriculture Organization of the United Nations: Rome, Italy, 2015; pp. 1-8. Available online: http://www.fao.org/3/a-i4068e.pdf (accessed on 20 February 2020).

9. Chaboud, G.; Daviron, B. Food losses and waste: Navigating the inconsistencies. Glob. Food Secur. 2017, 12, 1-7. [CrossRef]

10. Chaboud, G. Assessing food losses and waste with a methodological framework: Insights from a case study. Resources. Conserv. Recycl. 2017, 125, 188-197. [CrossRef]

11. Gustavsson, J.; Cederberg, C.; Sonesson, U.; van Otterdijk, R.; Meybeck, A. Global Food Losses and Food Waste: Extent Causes and Prevention; Food and Agriculture Organization of the United Nations (FAO): Rome, Italy, 2011; pp. 1-37. Available online: http://www.fao.org/3/mb060e/mb060e.pdf (accessed on 20 February 2020).

12. United Nations Transforming Our World. The 2030 Agenda for Sustainable Development; A/70/L.1; United Nations, General Assembly: New York, NY, USA, 2015; pp. 1-35. Available online: https://www.un.org/ga/ search/view_doc.asp?symbol=A/RES/70/1\&Lang=E (accessed on 20 February 2020).

13. Searchinger, T.; Waite, R.; Hanson, C.; Ranganathan, J.; Dumas, P.; Matthews, E. Creating a Sustainable Food Future: A Menu of Solutions to Feed Nearly 10 Billion People by 2050; World Resources Institute: Washington, DC, USA, 2019; pp. 1-556. Available online: https://reliefweb.int/report/world/world-resources-report-creatingsustainable-food-future-menu-solutions-feed-nearly-10 (accessed on 20 February 2020).

14. BCG Food and Agriculture Organization of the United Nations. Global Food Losses and Food Waste; BCG FLOW Model. 2015 Findings, in 2015 Dollars; FAOSTAT Database: Boston, MA, USA, 2018. Available online: https://www.consulting.us/news/860/global-food-wastage-could-hit-21-billion-tons-by-2030-instaggering-crisis (accessed on 20 February 2020). 
15. Hegnsholt, E.; Unnikrishnan, S.; Pollmann-Larsen, M.; Askelsdottir, B.; Gerard, M. Tackling the 1.6-Billion-Ton Food Loss and Waste Crisis; The Boston Consulting Group in Collaboration with Food Nation and State of Green: Boston, MA, USA, 2018. Available online: https://www.consulting.us/news/860/global-food-wastagecould-hit-21-billion-tons-by-2030-in-staggering-crisis (accessed on 20 February 2020).

16. CEC Technical Report. Quantifying Food Loss and Waste and its Impacts; Commission for Environmental Cooperation: Montreal, QC, Canada, 2019; pp. 1-129. Available online: http://www3.cec.org/islandora/en/ item/11813-technical-report-quantifying-food-loss-and-waste-and-its-impacts (accessed on 20 February 2020).

17. Popp, J.; Kiss, A.; Oláh, J.; Máté, D.; Bai, A.; Lakner, Z. Network analysis for the improvement of food safety in the international honey trade. Amfiteatr. Econ. 2018, 20,84-98. [CrossRef]

18. Popp, J.; Olah, J.; Fari, M.; Balogh, P.; Lakner, Z. The GM-regulation game-The case of Hungary. Int. Food Agribus. Manag. Rev. 2018, 21, 945-968. [CrossRef]

19. Gao, D. Food Loss and Waste; Building on Existing Federal Efforts Could Help to Achieve National Reduction Goal; GAO-19-391 United States Government Accountability Office: Washington, DC, USA, 2019; pp. 1-47. Available online: https://www.gao.gov/assets/gao-19-391.pdf (accessed on 20 February 2020).

20. European Commission. Frequently Asked Questions: Reducing Food Waste in the EU; European Commisison: Brussels, Belgium, 2019; pp. 1-5. Available online: https://ec.europa.eu/food/sites/food/files/safety/docs/fs_ eu-actions_fwm_qa-fight-food-waste.pdf (accessed on 20 February 2020).

21. Schweitzer, J.; Gionfra, S.; Pantzar, M.; Mottershead, D.; Watkins, E.; Petsinaris, F.; Ten Brink, P.; Ptak, E.; Lacey, C.; Janssens, C. Unwrapped: How Throwaway Plastic Is Failing to Solve Europe's Food Waste Problem (and What We Need to Do Instead); Institute for European Environmental Policy: Brussels, Belgium, 2018; pp. 1-28. Available online: http://www.foeeurope.org/sites/default/files/materials_and_waste/2018/unwrapped_-_ throwaway_plastic_failing_to_solve_europes_food_waste_problem.pdf (accessed on 20 February 2020).

22. European Commsission. Market Study on Date Marking and Other Information Provided on Food Labels and Food Waste Prevention, Final Report, Written by ICF in Association with Anthesis, Brook Lyndhurst, and WRAP January 2018; Directorate-General for Health and Food Safety: Brussels, Belgium, 2018; pp. 1-100. Available online: https://ec.europa.eu/food/sites/food/files/safety/docs/fw_lib_srp_date-marking.pdf (accessed on 14 March 2020).

23. Leib, E.B.; Gunders, D.; Ferro, J.; Nielsen, A.; Nosek, G.; Qu, J. The Dating Game: How Confusing Food Date Labels Lead to Food Waste in America; National Resources Defense Council: New York, NY, USA, 2013; pp. 1-61. Available online: https://cpb-us-e1.wpmucdn.com/blogs.uoregon.edu/dist/a/3266/files/2013/10/dating-gamereport-1m6z9a3.pdf (accessed on 20 February 2020).

24. Fanelli, R.M. Using causal maps to analyse the major root causes of household food waste: Results of a survey among people from Central and Southern Italy. Sustainability 2019, 11, 1183. [CrossRef]

25. Diaz-Ruiz, R.; Costa-Font, M.; López-i-Gelats, F.; Gil, J.M. Food waste prevention along the food supply chain: A multi-actor approach to identify effective solutions. Resour. Conserv. Recycl. 2019, 149, $249-260$. [CrossRef]

26. Conrad, Z.; Niles, M.T.; Neher, D.A.; Roy, E.D.; Tichenor, N.E.; Jahns, L. Relationship between food waste, diet quality, and environmental sustainability. PLoS ONE 2018, 13, e0195405. [CrossRef]

27. Fanelli, R.M. The interactions between the structure of the food supply and the impact of livestock production on the environment. A multivariate analysis for understanding the differences and the analogies across European Union countries. Qual. Acc. Success 2018, 19, 131-139.

28. Fanelli, R.M. The (un) sustainability of the land use practices and agricultural production in EU countries. Int. J. Environ. Stud. 2019, 76, 273-294. [CrossRef]

29. Swedish International Agricultural Network Initiative. Reducing Food Waste Across Global Food Chains; Policy Brief: Stockholm, Sweden, 2017; pp. 1-4. Available online: https://www.siani.se/wp-content/uploads/2017/ 10/policy_brief.pdf (accessed on 20 February 2020).

30. Ishangulyyev, R.; Kim, S.; Lee, S.H. Understanding Food Loss and Waste-Why Are We Losing and Wasting Food? Foods 2019, 8, 297. [CrossRef] [PubMed]

31. Nagpal, M.; Kumar, A. Grain losses in India and government policies. Qual. Assur. Saf. Crop. Foods 2012, 4, 143. [CrossRef] 
32. National Academy of Agricultural Sciences. National Academy of Agricultural Sciences Saving the Harvest: Reducing the Food Loss and Waste; Policy Brief No.5; National Academy of Agricultural Sciences: New Delhi, India, 2019; pp. 1-10. Available online: http://naasindia.org/documents/Saving\%20the\%20Harvest.pdf (accessed on 20 February 2020).

33. Abass, A.B.; Ndunguru, G.; Mamiro, P.; Alenkhe, B.; Mlingi, N.; Bekunda, M. Post-harvest food losses in a maize-based farming system of semi-arid savannah area of Tanzania. J. Stored Prod. Res. 2014, 57, 49-57. [CrossRef]

34. Manandhar, A.; Milindi, P.; Shah, A. An overview of the post-harvest grain storage practices of smallholder farmers in developing countries. Agriculture 2018, 8, 57. [CrossRef]

35. Kumar, D.; Kalita, P. Reducing postharvest losses during storage of grain crops to strengthen food security in developing countries. Foods 2017, 6, 8. [CrossRef]

36. Khader, B.F.Y.; Yigezu, Y.A.; Duwayri, M.A.; Nianed, A.A.; Shideed, K. Where in the value chain are we losing the most food? The case of wheat in Jordan. Food Secur. 2019, 11, 1009-1027. [CrossRef]

37. Borlaug, N. Increasing and Stabilizing Food Production. In Plant Breeding II; Frey, K.J., Ed.; Iowa State University Press: Ames, IA, USA, 1979; pp. 467-492.

38. International Grains Council. International Grains Council Grain Market Report Five-Year Baseline Projections of Supply and Demand for Wheat, Maize (Corn), Rice and Soyabeans to 2023/24 March 2019; International Grains Council: London, UK, 2019; pp. 1-4. Available online: http://www.igc.int/en/downloads/gmrsummary/ gmrsumme.pdf (accessed on 15 January 2020).

39. Popp, J.; Pető, K.; Nagy, P. Pesticide productivity and food security. A review. Agron. Sustain. Dev. 2013, 33, 243-255. [CrossRef]

40. Oerke, E.-C.; Dehne, H.-W. Safeguarding production-losses in major crops and the role of crop protection. Crop Prot. 2004, 23, 275-285. [CrossRef]

41. Oerke, E. Crop losses to pests. J. Agric. Sci. 2006, 144, 31-43. [CrossRef]

42. European Commission. European Commission Roadmap to a Resource Efficient Europe COM(2011) 571; European Commission: Brussels, Belgium, 2011. Available online: https://www.eea.europa.eu/policy-documents/com2011-571-roadmap-to (accessed on 10 January 2020).

43. European Commission. European Parliament EP Parliament Calls for Urgent Measures to Halve Food Wastage in the EU-Plenary Sessions; European Commission: Brussels, Belgium, 2020. Available online: https:/www.europarl.europa.eu/news/en/press-room/20120118IPR35648/parliament-callsfor-urgent-measures-to-halve-food-wastage-in-the-eu (accessed on 10 January 2020).

44. International Water Management Institute. Water for Food, Water for Life: A Comprehensive Assessment of Water Management in Agriculture; International Water Management Institute: London, UK, 2007; pp. 1-645. Available online: http://www.iwmi.cgiar.org/assessment/Publications/books.htm (accessed on 15 January 2020).

45. Leslie, J.; Logrieco, A. Mycotoxin Reduction in Grain Chains; Wiley Blackwell: Hoboken, NJ, USA, 2014.

46. Logrieco, A.; Visconti, A. An Introduction to the MycoRed Project. In Mycotoxin Reduction in Grain Chains; Leslie, J., Logrieco, A., Eds.; Wiley Blackwell: Hoboken, NJ, USA, 2014; pp. 1-7.

47. Godfrey, H.; Beddington, J.; Crute, I.; Haddad, L.; Lawrence, D.; Muir, J.; Pretty, J.; Robinson, S.; Thomas, S.; Toulmin, C. The Challenge of Feeding 9 Billion People. Science 2010, 12, 812-818. [CrossRef] [PubMed]

48. Kummu, M.; De Moel, H.; Porkka, M.; Siebert, S.; Varis, O.; Ward, P.J. Lost food, wasted resources: Global food supply chain losses and their impacts on freshwater, cropland, and fertiliser use. Sci. Total Environ. 2012, 438, 477-489. [CrossRef] [PubMed]

49. Cramer, H.-H. Plant protection and world crop production. Bayer Pflanzenschutz-Nachr. 1967, $20,1-524$.

50. Schumann, G.; D'Arcy, C. Essential Plant Pathology; APS Press: Sao Paulo, MN, USA, 2006.

51. Ubrizsy, G. Növényvédelmi Enciklopédia I. Általános Növényvédelem-Szántóföldi Növényvédelem-Encyclopedia of Plant Protection, Volume 1. General Plant Protection-Protection of Field Crops; Mezőgazdasági Kiadó-Agr Publ House: Budapest, Hungary, 1968.

52. Bradley, B.D.; Christodoulou, M.; Caspari, C.; Di Luc, P. Integrated Crop Managements Systems in the EU. Amended Final Report for European Commission DG Environment; Agra CEAS Consulting: Ashford, UK, 2002; pp. 1-141. Available online: https://ec.europa.eu/environment/agriculture/pdf/icm_finalreport.pdf (accessed on 14 March 2020). 
53. Bajwa, W.I.; Kogan, M. Compendium of IPM Definitions (CID)—What is IPM and how is it defined in the Worldwide Literature. IPPC Publ. 2002, 998, 1-14.

54. Ehler, L. Perspective Integrated pest management (IPM): Definition, historical development and implementation, and the other IPM Pest Management. Science 2006, 62, 787-789.

55. Kumar, D.; Shivay, Y. Modern Concepts in Agriculture, Integrated Crop Management; Indian Agricultural Research Institute: New Delhi, India, 2008; pp. 1-30. Available online: https://www.researchgate.net/publication/ 237569012 (accessed on 15 January 2020).

56. Vanlauwe, B.; Bationo, A.; Chianu, J.; Giller, K.E.; Merckx, R.; Mokwunye, U.; Ohiokpehai, O.; Pypers, P.; Tabo, R.; Shepherd, K.D. Integrated soil fertility management: Operational definition and consequences for implementation and dissemination. Outlook Agric. 2010, 39, 17-24. [CrossRef]

57. Bottrell, D. Ntegrated Pest Management. Record Number: 19810584265; United States Government Printing Office: Washington, DC, USA, 1979; pp. 1-120.

58. Barzman, M.; Bàrberi, P.; Birch, A.N.E.; Boonekamp, P.; Dachbrodt-Saaydeh, S.; Graf, B.; Hommel, B.; Jensen, J.E.; Kiss, J.; Kudsk, P. Eight principles of integrated pest management. Agron. Sustain. Dev. 2015, 35, 1199-1215. [CrossRef]

59. Lehoczki-Krsjak, S.; Varga, M.; Mesterházy, Á. Distribution of prothioconazole and tebuconazole between wheat ears and flag leaves following fungicide spraying with different nozzle types at flowering. Pest Manag. Sci. 2015, 71, 105-113. [CrossRef]

60. Mesterhazy, A.; Bartok, T. Control of Fusarium head blight of wheat by fungicides and its effect on the toxin contamination of the grains. Pflanzenschutz-Nachr. Bayer 1996, 49, 181-198.

61. Mesterházy, Á. Breeding Wheat for Fusarium Head Blight Resistance in Europe. In Fusarium Head Blight of Wheat and Barley; Bushnell, W., Ed.; APS Press: Sao Paulo, MN, USA, 2003; pp. 211-240.

62. Mesterházy, Á. Control of Fusarium Head Blight of Wheat by Fungicides. In Fusarium Head Blight of Wheat and Barley; Leonard, K., Bushnell, W., Eds.; APS Press: Sao Paulo, MN, USA, 2003; pp. 363-380.

63. Mesterházy, Á.; Tóth, B.; Varga, M.; Bartók, T.; Szabó-Hevér, Á.; Farády, L.; Lehoczki-Krsjak, S. Role of fungicides, application of nozzle types, and the resistance level of wheat varieties in the control of Fusarium head blight and deoxynivalenol. Toxins 2011, 3, 1453-1483. [CrossRef] [PubMed]

64. Mesterházy, Á.; Varga, M.; György, A.; Lehoczki-Krsjak, S.; Tóth, B. The role of adapted and non-adapted resistance sources in breeding resistance of winter wheat to Fusarium head blight and deoxynivalenol contamination. World Mycotoxin J. 2018, 11, 539-557. [CrossRef]

65. Mesterházy, Á.; Varga, M.; Tóth, B.; Kotai, C.; Bartók, T.; Véha, A.; Ács, K.; Vágvölgyi, C.; Lehoczki-Krsjak, S. Reduction of deoxynivalenol (DON) contamination by improved fungicide use in wheat. Part 1 . Dependence on epidemic severity and resistance level in small plot tests with artificial inoculation. Eur. J. Plant Pathol. 2018, 151, 39-55. [CrossRef]

66. Lamichhane, J.R.; Arseniuk, E.; Boonekamp, P.; Czembor, J.; Decroocq, V.; Enjalbert, J.; Finckh, M.R.; Korbin, M.; Koppel, M.; Kudsk, P. Advocating a need for suitable breeding approaches to boost integrated pest management: A European perspective. Pest Manag. Sci. 2018, 74, 1219-1227. [CrossRef] [PubMed]

67. Jayas, D.S. Storing grains for food security and sustainability. Agric. Res. 2012, 1, 21-24. [CrossRef]

68. Philip, T.; Throne, J. Biorational approaches for managing stored-product insect. Annu. Rev. Entomol. 2010, 55, 375-397. [CrossRef]

69. World Health Organisation. Aflatoxins, REF. No.: WHO/NHM/FOS/RAM/18; World Health Organisation, Department of Food Safety and Zoonoses: Geneva, Switzerland, 2018; pp. 1-5. Available online: https: //www.who.int/foodsafety/FSDigest_Aflatoxins_EN.pdf (accessed on 20 February 2020).

70. Kumar, R.; Mishra, A.K.; Dubey, N.; Tripathi, Y. Evaluation of Chenopodium ambrosioides oil as a potential source of antifungal, antiaflatoxigenic and antioxidant activity. Int. J. Food Microbiol. 2007, 115, 159-164. [CrossRef]

71. Dowling, T. Fumonisin and its toxic effects. Cereal Foods World 1997, 42, 13-15.

72. McMullen, M.; Jones, R.; Gallenberg, D. Scab of wheat and barley: A re-emerging disease of devastating impact. Plant Dis. 1997, 81, 1340-1348. [CrossRef]

73. Szabo, B.; Toth, B.; Toth Toldine, E.; Varga, M.; Kovacs, N.; Varga, J.; Kocsube, S.; Palagyi, A.; Bagi, F.; Budakov, D. A New Concept to Secure Food Safety Standards against Fusarium Species and Aspergillus Flavus and Their Toxins in Maize. Toxins 2018, 10, 372. [CrossRef] 
74. Alexander, P.; Brown, C.; Arneth, A.; Finnigan, J.; Moran, D.; Rounsevell, M.D. Losses, inefficiencies and waste in the global food system. Agric. Syst. 2017, 153, 190-200. [CrossRef]

75. Caldeira, C.; Caldeira, C.; Sara, C.; Serenella, S. Food Waste Accounting: Methodologies, Challenges and Opportunities. JRC109202; 9279778889; Publications Office of the European Union: Brussels, Belgium, 2017.

76. Food and Agriculture Organization of the United Nations. Food Loss and Waste Facts; Food and Agriculture Organisation of the United Nations: Rome, Italy, 2019. Available online: http://www.fao.org/3/a-i4807e.pdf (accessed on 10 January 2020).

77. Mesterházy, Á. Breeding for Resistance against FHB in Wheat. In Mycotoxin Reduction in Grain Chains: A Practical Guide; Logrieco, A.F., Visconti, A., Eds.; Blackwell-Wiley: Hoboken, NJ, USA, 2014; pp. 189-208.

78. Mesterházy, A.; Lehoczki-Krsjak, S.; Varga, M.; Szabó-Hevér, Á.; Tóth, B.; Lemmens, M. Breeding for FHB Resistance via Fusarium Damaged Kernels and Deoxynivalenol Accumulation as Well as Inoculation Methods in Winter Wheat. Agric. Sci. 2015, 6, 970-1002.

79. Jans, D.; Pedrosa, K.; Schatzmayr, D.; Bertin, G.; Grenier, B. Mycotoxin Reduction in Animal Diets. In Mycotoxin Reduction in Grain Chains; Logrieco, A.F., Visconti, A., Eds.; Wiley: Oxford, UK, 2014; pp. 101-110.

80. Edwards, S.G.; Jennings, P. Impact of agronomic factors on Fusarium mycotoxins in harvested wheat. Food Addit. Contam. Part A 2018, 35, 2443-2454. [CrossRef] [PubMed]

81. Cowger, C.; Weisz, R.; Arellano, C.; Murphy, P. Profitability of integrated management of Fusarium head blight in North Carolina winter wheat. Phytopathology 2016, 106, 814-823. [CrossRef] [PubMed]

82. Zorn, A.; Musa, T.; Lips, M. Costs of preventive agronomic measures to reduce deoxynivalenol in wheat. J. Agric. Sci. 2017, 155, 1033-1044. [CrossRef]

83. Baranski, M.R. Wide adaptation of Green Revolution wheat: International roots and the Indian context of a new plant breeding ideal, 1960-1970. Stud. Hist. Philos. Sci. Part C 2015, 50, 41-50. [CrossRef]

84. Wang, J.; Vanga, S.K.; Saxena, R.; Orsat, V.; Raghavan, V. Effect of climate change on the yield of cereal crops: A review. Climate 2018, 6, 41. [CrossRef]

85. Tilman, D.; Balzer, C.; Hill, J.; Befort, B.L. Global food demand and the sustainable intensification of agriculture. Proc. Natl. Acad. Sci. USA 2011, 108, 20260-20264. [CrossRef]

(C) 2020 by the authors. Licensee MDPI, Basel, Switzerland. This article is an open access article distributed under the terms and conditions of the Creative Commons Attribution (CC BY) license (http://creativecommons.org/licenses/by/4.0/). 